Marco Aurélio Pinheiro Lima; Alexandra Pardo Policastro Natalense. "THE NEED FOR BASIC RESEARCH IN THE SUGARCANE/ETHANOL PRODUCTION CYCLE", p.151-156. In Luis Augusto Barbosa Cortez (Coord.). Sugarcane bioethanol - R\&D for Productivity and Sustainability, São Paulo: Editora Edgard Blücher, 2014. http://dx.doi.org/10.5151/BlucherOA-Sugarcane-SUGARCANEBIOETHANOL_18

\title{
THE NEED FOR BASIC RESEARCH IN THE SUGARCANE/ETHANOL PRODUCTION CYCLE
}

\section{Marco Aurélio Pinheiro Lima and Alexandra Pardo Policastro Natalense}

Brazil does not usually create its own technological agenda. With some exceptions, such as the deep sea oil exploration developed by Petrobras ${ }^{[1]}$ and the Complete Brazilian Space Mission ${ }^{[2]}$, the scientific development of the country is directed to attend the technological demands imposed by other countries, especially the most developed. Identifying a clear and well defined goal is an interesting strategy to guide the scientific and technological development needed to achieve this mission. Actually, this development can produce several results in different areas, which may seem very diverse from the original goal, at a first glance. For instance, several examples could be cited as consequences of the Nasa's space program ${ }^{[3]}$, such as the development of infrared auricular thermometers, solar cells, radial tires improvement, fire sensors etc.

Nowadays, the need for mitigating greenhouse gas emissions, such as $\mathrm{CO}_{2}$, has become a global challenge. One of the many ways for contributing to this task is to reduce the use of fossil fuels by replacing them for biofuels obtained from renewable sources. In this sense, Brazil was the first country to use fuel ethanol in automobiles un large scale after the National Alcohol Program - Proalcool in 1975 , and has also a privileged position in the world's scenario with the recently developed flex fuel engines.

Brazil and the United States are the biggest ethanol producers in the world. Brazilian ethanol, produced from the sugarcane juice, has an 1 to 8 energy balance, while for American ethanol, produced from corn starch, the balance is 1 to
$1.3^{[4]}$. The raw material is responsible for most of this advantage: the sugarcane juice is already $20 \%$ sugar while the corn starch needs to be hydrolysed so that the resulting sugars can be fermented ${ }^{[4]}$.

Sugarcane producing countries lay at latitudes between 36.7 and 31 south from Equator line ${ }^{[5]}$. Among them, Brazil is the largest producer with $30.2 \%$ of the total area dedicated to sugarcane crop in the world, followed by India with $20.6 \%$ and China with $6 \%{ }^{[6]}$. These data, among others, show that Brazil has the most favorable conditions to embrace the sugarcane/ethanol cycle as a truly Brazilian technological agenda.

In 2005, the Ethanol Project Report ${ }^{[7]}$, produced by the consortium Nipe - Unicamp/CGEE - MCT showed that Brazil could produce enough ethanol to replace $10 \%$ of the gasoline consumed in the world by 2025. To do so, it would be necessary an annual production of 205 billion liters of ethanol. According to the preliminary 2008 National Energy Balance - BEN, Brazilian production in 2007 was 22.557 billion liters of ethanol. This raise in the production can only be reached if investments are made in science and technology of the whole sugarcane/ethanol production cycle, ranging from the choice of the best areas for cropping without displacing food crops or deforesting, to improvements in the cultivation techniques, industrial processes, product distribution etc.

An expressive increase in the ethanol production implies in a substantial increase in the productivity of the planted area. Many factors can influence this increase in the productivity, and one of them (maybe the most expressive), is the 
possibility of using the whole sugarcane biomass as a raw material for ethanol production, not only the juice. It is estimated that this could result in an increase of about $40 \%$ in the production of one determined planted area. An efficient technology for conversion of lignocellulosic material from the bagasse and trash in ethanol needs to be developed, tested and adapted for use in industrial scale.

The three main components of lignocellulose are cellulose, hemicellulose and lignin. Lignin is an aromatic polymer that binds cellulose and hemicellulose together, providing rigidity and resistance to humidity. Cellulose and hemicellulose are composed by chains of sugar molecules that can be hydrolysed to produce monomers. This step represents a great technological challenge, since it is necessary not only to dominate the hydrolysis process, but also to use it in industrial scale.

Some of the sugar monomers (hexoses) can be directly fermented to ethanol by yeast. On the other hand, pentoses (five carbon sugars) can't. This is one of the important scientific challenges in the process. Pentoses (xylose and arabinose) and hexoses (glucose, manose, and galactose) are sugars that compose hemicellulose, among other components. The constituents of lignocellulosic material vary for each vegetable species. For instance, wood from conifer contain about 6\% to $7 \%$ of pentoses ${ }^{[8]}$, and therefore, it is important to use these sugars in the ethanol production to help in the development of an economically viable process. To do so, it is necessary to develop a genetically modified microorganism, able to efficiently ferment pentoses into ethanol. Another alternative would be to use pentoses in some other kind of process. For example, xylose can be used as a carbon source for bacteria that synthesize polyhidroxyalcanoates, which are natural thermoplastics, used as carbon and energy reserves ${ }^{[9]}$. There is a great commercial interest on this kind of polyester because they are obtained from renewable sources. The most efficient utilization of pentoses, considering the costs and benefits for the ethanol production chain is a problem that needs to be studied.

The process of converting lignocellulosic biomass into ethanol is far more complex than it seems. In principle, fast growing trees, grass, agri- cultural and forestry residues and others could be used as low-cost feedstock. However, heterogeneity in these raw material require different process conditions on feedstock preparation, microorganisms and enzymes, which makes the biomass-toethanol conversion complex ${ }^{[8]}$. This complexity is also present when sugarcane bagasse is used. The bagasse that comes out of the last mill in a sugarcane processing plant contains heterogeneous particles with sizes between $1 \mathrm{~mm}$ and $25 \mathrm{~mm}$ (with an average of $20 \mathrm{~mm}$ ). This particle sizing depends on the sugarcane preparation and milling processes. The morphologic composition of the bagasse includes external fibers from the stalk and skin which are rigid, contain high levels of lignin, thick cell walls and protect the stalk from mechanical external effects; vascular bundles and other fibrous forms which contribute for the sustentation of the plant and drive foods and elaborated products along the stalk; parenchyma, usually called pith, which has the function of storing the juice ${ }^{[10]}$. The paper and cellulose industry separates the pith to be used for head and power production and uses the fiber in its production process. The two fractions themselves are more homogeneous than the whole bagasse and look very different from each other, as seen in Figure 1, which shows a sample taken from sugarcane bagasse at Bioethanol Science and Technology Center ${ }^{[11]}$. These are images from electron scan microscopy made at Centro de Nanociência e Nanotecnologia Cesar Lattes - LME at Brazilian Synchrotron Light Laboratory.

The separation in two fractions (fiber and pith) may or may not represent an advantage for enzymatic hydrolysis and the advantages and/ or disadvantages of this procedure must still be studied. The point is that it is necessary to define a physical pretreatment that produces a stable and homogeneous material as feedstock for the hydrolysis process. From this starting point, the results of the scientific research to be done downstream can be reproduced.

Ethanol production from sugarcane bagasse can be done using several different routes. One of them is the enzymatic hydrolysis of lignocellulosic material, which produces sugar monomers. One of the hindrances of this process is that the material 


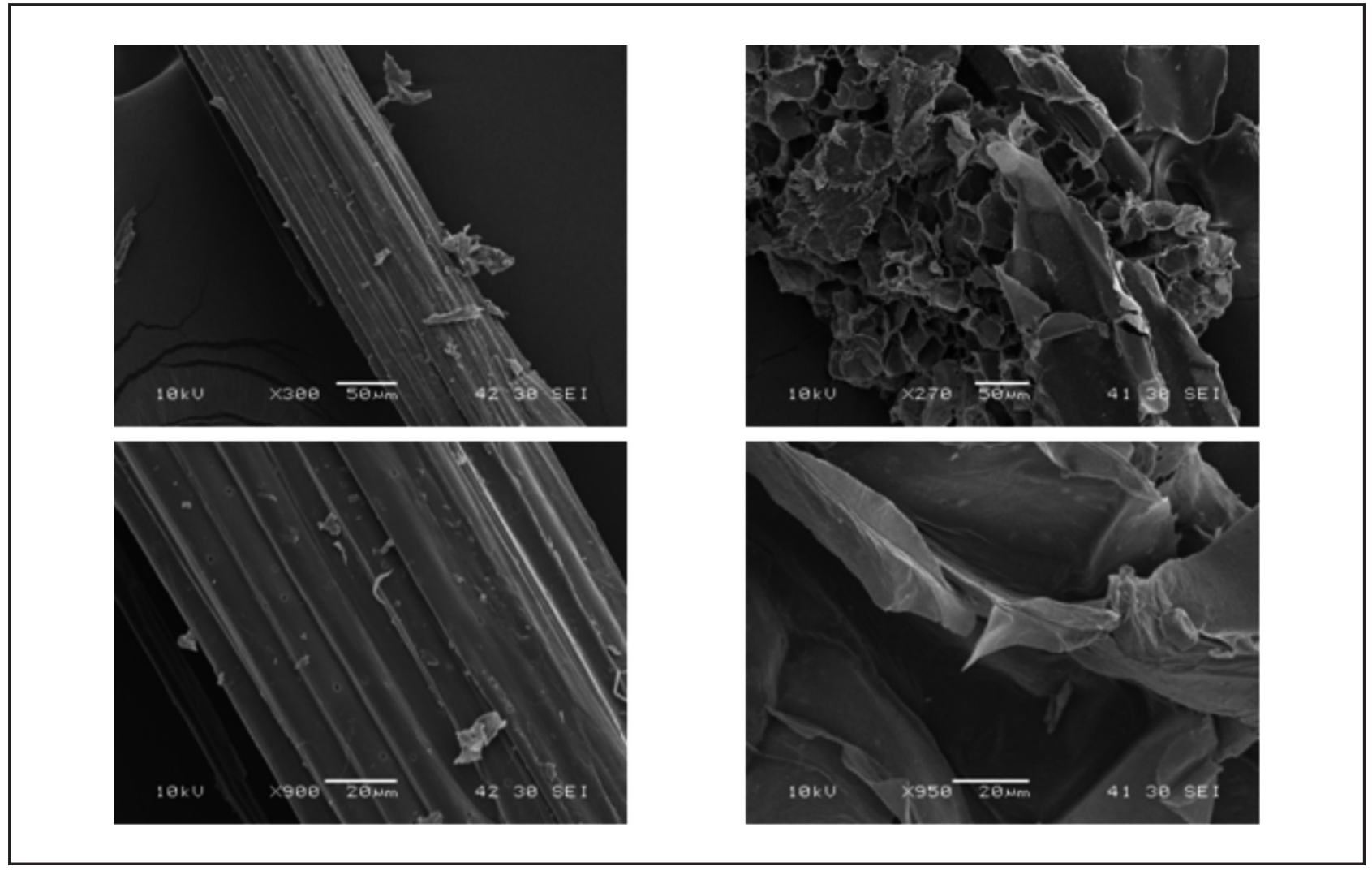

FIGURE 1 Image from electron scan microscope of the two fractions of sugarcane bagasse: left: fiber; right: pith.

is highly crystalline, which requires a pretreatment to expose cellulose, facilitating the action of enzymes. A physical pretreatment as described above could make this task easier since the efficiency of the enzymatic attack is influenced by the material surface available to enzymes. However, lignin is a cellulase inhibitor, and, therefore, there is a need to reduce its percentage in the solid material. There are many different types of pretreatment described in the literature and each one of them have their advantages and disadvantages ${ }^{[12]}$. The use of one or several pretreatments in association with a better understanding of the structure and composition of the bagasse will determine the success of the chosen method to favor the hydrolysis process. This association should result from scientific research concerning the knowledge of the structure and composition of the material before and after the pretreatment.

Efficient enzymes production at high yields is another scientific challenge to overcome. Cellulases are a group of enzymes that work together to degrade cellulose fibers. Fungi and bacteria that live in contact with cellulosic material can produce cellulases. There are many studies on fungi, since they are aerobic and produce at high rates. There has been many advances on the knowledge about cellulase action, but there is still a long way to go before efficient enzymatic complexes can be developed $^{[13]}$. This development can be done if the knowledge on the structure and composition of the pretreated material, as mentioned above, is associated with deep understanding on how enzymes act on it.

Historically, the production of Brazilian ethanol started in association with sugar production. The enzymatic route for cellulosic ethanol production could be attached to nowadays sugar mills so that it could use the bagasse as raw material, after the juice extraction for sugar or first generation ethanol production. However, we should keep in mind that alternative routes for cellulosic ethanol production could be more efficient than an attachment to the current technology. One could think 
about using the whole sugarcane plant in a route that could convert it directly into final products or into feedstock through thermochemical processes such as pyrolysis or gasification. There is a need for a study of the viability of technological routes independently of the existing technologies.

Moreover, the mechanism for breaking the sugar chains of cellulose also need to be studied in much greater detail. For instance, it is known in the literature that low energy electrons generated by the interaction of ionizing radiation with cellules can cause the breaking of DNA molecules ${ }^{[14]}$. Motivated by this study, the electron molecule scattering scientific community have been working on the interaction of low energy electrons with smaller molecules which are similar to DNA components ${ }^{[15]}$. This results indicate that electrons could interact with the cellulose chain and cause its breaking down. One of the interesting basic research areas would be the study of this interaction, especially if shape resonances are present, which could cause molecular dissociation through electron capture. This kind of study could bring a new light to the understanding of the cellulose breaking process, which could also help unveiling enzymes cleavage mechanism.

The main goal of all the studies described above is a substantial increase in the ethanol production. However, this increase itself is not enough. Keeping production costs as low as possible is essential. Considering that 70\% of Brazilian ethanol production costs are related to agricultural processes, it is important that science can also contribute to minimize them. In this sense, many progress have been made to develop new sugarcane varieties. For example, Instituto Agronômico - IAC, a research institute related to the Agência Paulista de Tecnologia dos Agronegócios from the Secretary of Agriculture of São Paulo State, has been developing regional varieties of sugarcane since 1933 through clone selection ${ }^{[16]}$. Ridesa Rede Interuniversitária para Desenvolvimento do Setor Sucroalcooleiro also uses this technique and has been working with clones evaluation related to diseases, plagues and productivity in different production environment ${ }^{[17]}$. According to Ridesa, it takes around 13 years of research work until a new variety is available for sugarcane producers. CTC - Centro de Tecnologia Canavieira has launched over 60 varieties of sugarcane, all developed through conventional improvement ${ }^{[18]}$. Although these programs are successful, new varieties could be developed through genetic engineering techniques so that the plant could be available for the producer in a shorter time. Moreover, most of the improvement programs focus on increasing the sugar content in the plant, and this improvement has been slow along the last few decades. This could indicate that basic research on the causes of this slow progress should be associated with alternative strategies for genetic improvement ${ }^{[19]}$. Recent publications show that photosynthetic activity is modulated by the amount of sugar in the stalk and point out that there is a lack of deeper research on this subject ${ }^{[20,21]}$.

Sugarcane is a grass originated from Asia. It is one of the most efficient plants in producing carbohydrates from photosynthesis, as has been well known for over 50 years ${ }^{[22]}$. Nevertheless, studies on sugarcane photosynthesis are scarce in the literature. Some of the studies found by these authors show that the photosynthesis of a young plant is much more efficient than the one of the adult plant ${ }^{[23]}$. Others show the influence of hydrous stress on the enzymatic activities associated with photosynthesis ${ }^{[24]}$ or the influence of water excess due to flooding in the Everglades (Florida) on photosynthesis, transpiration and others $^{[25]}$. All these studies are important steps, but the fact is that there are not more profound studies in the literature on the basic operation of sugarcane photosynthesis process, considering its physical, chemical and biochemical aspects.

Other important points to be considered are the farming and harvesting of sugarcane. Nowadays, harvesting mechanization has become needful, since the demand for $\mathrm{CO}_{2}$ emissions mitigation is increasing every year and burning the field previous to hand cutting is no longer an accepted practice. The adopted mechanized system is the chopped cane harvesting. This system was developed simultaneously in Cuba and in Australia and allows the elimination of burning, by introducing the bulk handling of sugarcane and pneumatic 
trash removal. However, although this type of mechanization represents a great progress in the sector, it still presents several restrictions such as losses in the transport loading ${ }^{[26]}$ and in the trash removing processes, soil movement resulting in high levels of impurities in the load ${ }^{[27]}$, soil compaction between rows, restriction for use in fields with maximum of $12 \%$ slope, incompatibility with no-till farming system etc. The implementation of no-till farming of sugarcane is highly desirable, since it was shown that the system has contributed for the reduction of losses of soil and water in cereals farming ${ }^{[28]}$ and it is expected that the results for sugarcane should be similar. Actually, the minimum tillage application has produced a raise in the average productivity from 89.8 t/ha (conventional farming) to $98.2 \mathrm{t} / \mathrm{ha}^{[29]}$. It is necessary, therefore, to develop a new technology for sugarcane farming to overcome the difficulties faced by the actual mechanization system, which can also contribute to the implementation of no-till farming of sugarcane and for the effective use of precision agriculture.

The use of ethanol as a renewable liquid fuel and as feedstock to chemical industries is of fundamental importance for a more sustainable global scenario. Making people's daily activities more sustainable is a challenge. We recall that along its history, humankind has never been worried with ecosystem's preservation or preservation of the planet as a whole. Damages caused by the industrialization process and by the use of fossil fuels are now evident and grow at a quick rate. Taking sustainable attitudes is fundamentally a change in behavior that begins with education. Besides, it is necessary an in-depth study of the impacts that the development of new technologies can bring to the social and economical progress of the country.

The basic research in the sugarcane/bioethanol cycle still has several obstacles to overcome. It is important to notice the interdisciplinary character of the task, involving problems in the areas of chemistry, biochemistry, physics, mathematical modeling, microbiology, chemical engineering and materials, among others. There is, therefore, the need for human resources in those areas (and related ones), highly qualified, that can interact with each other to collaborate in an efficient and dynamic way in order to attack the problem from different points of view and to formulate creative and solutions for the bottlenecks of the process. Therefore, the commitment of the whole national scientific community in this area is of fundamental importance, so that, joining efforts, we can contribute to maintain the Brazilian leadership in the sustainable production of bioethanol from sugarcane.

\section{ACKNOWLEDGEMENTS}

The authors thank researchers C. E. V. ROSSELL, D. R. FRABETTI, E. O. GOMEZ, F. M. SQUINA, J. G. C. PRADELLA, O. A. BRAUNBECK, M. P. CUNHA and M. R. L. V. LEAL for fruitful discussions. The authors would like to thank the LME/LNLS for technical support during electron microscopy work.

\section{REFERENCES}

1. Available at: <www.petrobras.com $>$.

2. Available at: <www.aeb.gov.br $>$.

3. Available at: <www.nasa.gov/topics/nasalife/index.html>.

4. National Geographic, October, 38 (2007).

5. Available at: <www.sugarcanecrops.com/p/introduction $>$.

6. FAO, 2008.

7. Estudo coordenado por R. C. de C. Leite, com a participação de vários pesquisadores do Núcleo Interdisciplinar de Planejamento Estratégico - NIPE/UNICAMP, com apoio financeiro do CGEE - Centro de Gestão e Estudos Estratégicos.

8. GALBE, M.; ZACCHI, G. Appl. Microbiol. Biotechnol 59, 618 (2002).

9. SILVA, L. F.; TACIRO, M. K.; RAMOS, M. E. M.; J. M. CARTER; PRADELLA, J. G. C.; GOMEZ, J. G. C. J. Ind. Microbiol. Biotechnol 31, 245 (2004).

10. Manual dos derivados da cana-de-açúcar: diversificação, matérias-primas, derivados do bagaço, derivados 
do melaço, outros derivados, resíduos, energia - Brasília - Abipti, capítulo 2.3, p. 37 (1999).

11. GOMEZ, E. O.; SQUINA, F. M., private communication.

12. CHANDRA, R. P.; BURA, R.; MABEE, W. E.; BERLIN, A.; PAN, X.; SADDLER, J. N. Adv. Biochem Engin/ Biotechnol 108, 67 (2007).

13. HAMELINCK, C. N.; VAN HOOIJDONK, G.; FAAIJ, A. P. C. Biomass and Bioenergy 28, 384 (2005).

14. BOUdAÏFFA, B.; CLOUTIER, P.; HUNTING, D.; HUELS, M. A.; SANCHE, L. Science, 287, 1658 (2000); SANCHE, L. Eur. Phys. J. D, 35, 367 (2005); MARTIN, F.; BURROW, P. D.; CAI, Z.; CLOUTIER, P.; HUNTING, D.; SANCHE, L. Phys. Rev. Lett. 93, 068101 (2004).

15. WINSTEAD, C.; MCKOY, V. J. Chem. Phys. 125, 074302 (2006); BOUCHIHA, D.; GORFINKIEL, J. D.; CARON, L. G.; SANCHE, L. J. Phys. B 39, 975 (2006); RESCIGNO, T. N.; TREVISAN, C. S.; OREL, A. E. Phys. Rev. Lett. 96, 213201 (2006); ALLAN, M. J. Phys. B, 39, 2939 (2006); BETTEGA, M. H. F.; LIMA, M. A. P. J. Chem. Phys. 126, 194317 (2007) e referências citadas.

16. Available at: <www.iac.sp.gov.br/centros/centrocana/ principal.htm $>$.

17. Available at: <www.ridesa.org.br/mgenetico.htm>.

18. Available at: <www.ctcanavieira.com.br/index. php?option=com_content\&task=view\&id=46\&Itemid=> .
19. JACKSON, P. A. Field Crops Research 92, 277 (2005).

20. McCORMICK, A. J.; CRAMER, M. D.; WATT, D. A. J. of Plant Physiol 165, 1817 (2008).

21. McCORMICK, A. J.; CRAMER, M. D.; WATT D. A. Annals of Botany 101, 89 (2008).

22. LEDON, A. C.; GONZALES, F. A. Z. Proc. Cuban Sugar Technol 24, 563 (1950).

23. BARET, P.; CESARI, M.; QUEIROZ, C.; ROUCH, C.; MEUNIER, J. C.; CADET, F.; ACAD, C. R. Sci. Paris, Sciences de la Vie/Life Sciences, 322, 29 (1999).

24. DU, Y. C.; NOSE, A.; WASANO, K.; UCHIDA, Y. Aust. J. Plant Physiol 25, 253 (1998)

25. GLAZ, B.; MORRIS, D. R.; DAROUB, S. H. Crop. Sci. 44, 1633 (2004).

26. MAGALHÃES, P. S. G.; BALDO, R. F. G.; CERRI, D. G. P. System of Synchronism Between Sugarcane Harvest Machine And Infield Wagon, Engenharia Agrícola, 28, 274-282 (2008).

27. GRAY, G. R.; MAGALHÃES, P. S. G.; BRAUNBECK, O. A. Suspensão pantográfica para corte de canade-açúcar, Ciência Rural, Santa Maria, Online, ISSN 0103-8478.

28. Agência Nacional de Águas - ANA, 2006.

29. Revista Canavieiros, mar. 2007 - Marcelo Felício, Eng. Agr. Canaoeste. 